\title{
HIF-1 $\alpha$ contributes to tube malformation of human lymphatic endothelial cells by upregulating VEGFR-3
}

\author{
TAO HAN ${ }^{*}$, JUN YAN ${ }^{*}$, HAINI CHEN, YI JI, \\ JIANBING CHEN, JIE CUI, WEIMIN SHEN and JIJUN ZOU \\ Department of Burns and Plastic Surgery, Children's Hospital of Nanjing \\ Medical University, Nanjing, Jiangsu 210008, P.R. China
}

Received June 18, 2018; Accepted October 12, 2018

DOI: $10.3892 /$ ijo.2018.4623

\begin{abstract}
Hypoxia-inducible factor- $1 \alpha$ (HIF- $1 \alpha)$ is upregulated in various tumors and associated with lymphangiogenesis and angiogenesis during tumor development and metastasis. However, the role of HIF-1 $\alpha$ in cystic lymphatic malformations (cLM) remains unclear. In the present study, expression of HIF-1 $\alpha$ and vascular endothelial growth factor receptor 3 (VEGFR-3) was evaluated in 20 pairs of cLM specimens from patients who accepted curative surgery at Children's Hospital of Nanjing Medical University (Nanjing, China). Additionally, a stable HIF-1 $\alpha$-overexpressing human lymphatic endothelial cell (HLEC) line was established. Overexpression and silencing of HIF-1 $\alpha$ were used to investigate the biological role in colony formation, migration and lymphatic tube formation. HIF-1 $\alpha$ and VEGFR-3 were upregulated in cLM specimens compared with adjacent normal tissues. In addition, HIF-1 $\alpha$ effectively induced HLEC colony formation and migration. Furthermore, lymphatic malformation of HLECs was promoted in vitro by overexpression of HIF-1 $\alpha$. HIF-1 $\alpha$ overexpression upregulated VEGFR-3 during lymphangiogenesis. Additionally, expression of lymphatic endothelial markers prospero homeobox protein 1 and lymphatic vessel endothelial hyaluronan receptor 1 increased significantly during lymphatic tube malformation. The presented data demonstrated that HIF-1 $\alpha$ overexpression in HLECs promoted colony formation, migration and tube malformation via upregulation of VEGFR-3. These findings
\end{abstract}

Correspondence to: Professor Weimin Shen and Dr Jijun Zou, Department of Burns and Plastic Surgery, Children's Hospital of Nanjing Medical University, 72 Guangzhou Road, Nanjing, Jiangsu 210008, P.R. China

E-mail:swmswmswm@sina.com

E-mail: 5098782@qq.com

*Contributed equally

Key words: hypoxia-inducible factor-1 $\alpha$, vascular endothelial growth factor receptor 3, cystic lymphatic malformation, human lymphatic endothelial cell may assist in the development of HIF-1 $\alpha$-targeted cLM therapeutics in the future.

\section{Introduction}

Lymphatic malformations are non-malignant masses that result from the abnormal development of the lymphatic vessels $(1,2)$. Cystic lymphatic malformations (cLM) comprise a significant portion of congenital lymphatic malformation and can be classified into three histological subtypes based on the diameter of the cyst, including macrocystic $(>1 \mathrm{~cm})$, microcystic $(<1 \mathrm{~cm})$ and mixed-type (3). While the exact etiology is unknown, cLM is believed to result from the loss of connection between local lymphatic tissues and the lymphatic or vascular systems during critical development stages of the lymphatic system $(4,5)$. While the genetics and molecular mechanisms underlying hemangiomas and vascular malformations have been elucidated (6-8), those of cLM remain unknown at this time.

Hypoxia-inducible factor-1 (HIF-1) is a protein complex that consists of two similar subunits, HIF- $1 \alpha$ and HIF-1 $\beta$. Biological roles of HIF-1 include mediation of hypoxia on cells and regulation of the metabolism $(9,10)$. The HIF-1 cascade occurs when HIF- $1 \alpha$ binds to HIF- $1 \beta$ in the cell nucleus under hypoxic conditions. Several researchers are currently investigating the role of HIF-1 $\alpha$ in lymphangiogenesis and angiogenesis during tumor development $(11,12)$. Unlike blood vessels, lymphatic vessels are exposed to an oxygen-deprived environment due to the lack of oxygen-carrying red blood cells. In hypoxic milieus, tumor cells enhance the growth of lymphatic vessels by increasing the production of vascular endothelial growth factor (VEGF)-C, which provides a route for tumor cells metastasis (13).

VEGF receptor 3 (VEGFR-3), which is primarily localized to lymphatic endothelial cells, is the tyrosine kinase receptor of VEGF-C and its signaling pathway has been demonstrated to associated with lymphatic vascular development during multiple stages (14). Angiopoietin-1-induced upregulation of VEGFR-3 activates sprouting and hyperplasia of lymphatic vessels (15). Previous studies have suggested that hypoxia upregulates the expression of VEGFR-3 and VEGF-C in several cancer cell lines, which yields a significant and vital association between HIF-1 $\alpha$ and VEGFR-3 (16-18). Although 
the existence of the HIF-1 $\alpha$ /VEGFR-3/VEGF-C axis has been demonstrated in tumor lymphangiogenesis, it is unknown if the axis serves a crucial role in the malformation of lymphatic vessels.

The current study aimed to assess the biological function of HIF-1 $\alpha$ in the malformation of human lymphatic endothelial cells (HLECs) via regulation of VEGFR-3. The results have demonstrated that HIF-1 $\alpha$ expression was upregulated in human CLM specimens compared with normal tissue, which in turn upregulated VEGFR-3 expression and in vitro led to the promotion of colony formation, migration and tube malformation in HLECs.

\section{Materials and methods}

Clinical data and sample collection. cLM and matched cLM-adjacent normal tissues were obtained from 20 patients (median age, 12.5 months; age range, 16 days to 5 years; male, 11; female, 9), who underwent surgical resection or a combined operation (endoscopic cautery and postoperative intratumoral negative pressure) (19) in the Department of Burns and Plastic Surgery at the Children's Hospital of Nanjing Medical University (Nanjing, China) between August 2015 and May 2016. Clinical characteristics of the patients are summarized in Table I. All tissue samples were immediately frozen in liquid nitrogen following resection and stored at $-80^{\circ} \mathrm{C}$ for subsequent experiments. The study protocol was approved by the Ethics Committee of Children's Hospital of Nanjing Medical University (Nanjing, China). Written consent was obtained prior to the initiation of the study.

Cell culture. HLECs (cat. no. 2500) were obtained from the Type Culture Collection of the Chinese Academy of Sciences (Shanghai, China). Cells were cultured in endothelial cell medium (ECM; ScienCell Research Laboratories, Inc., San Diego, CA, USA) in a humidified atmosphere containing $5 \% \mathrm{CO}_{2}$ at $37^{\circ} \mathrm{C}$.

$R N A$ isolation and reverse transcription-quantitative polymerase chain reaction $(R T-q P C R)$. Total RNA was isolated from the tissues and cells using TRIzol reagent (Invitrogen; Thermo Fisher Scientific, Inc., Waltham, MA, USA) according to the manufacturer's instructions. RNA quantity was measured using a NanoDrop 2000 spectrophotometer (Thermo Fisher Scientific, Inc.) and RNA quality was assessed via gel electrophoresis. cDNA was synthesized from total RNA $(1 \mu \mathrm{g})$ using the PrimeScript ${ }^{\circledR}$ RT kit (Takara Biotechnology Co., Ltd., Dalian, China) according to the manufacturer's instructions by incubation at $37^{\circ} \mathrm{C}$ for $15 \mathrm{~min}$, followed by $85^{\circ} \mathrm{C}$ for $5 \mathrm{sec}$ and storage at $4^{\circ} \mathrm{C}$. qPCR was performed using the SYBR Green PCR master mix (Takara Biotechnology Co., Ltd.) in $20 \mu \mathrm{l}$ reactions according to the manufacturer's instructions. Expression of the target genes was relative to that of $\beta$-actin. The reaction protocol included incubations at $95^{\circ} \mathrm{C}$ for $30 \mathrm{sec}$, followed by 40 cycles of $95^{\circ} \mathrm{C}$ for $5 \mathrm{sec}$ and $60^{\circ} \mathrm{C}$ for $30 \mathrm{sec}$. All reactions were performed in triplicate and quantification was performed using the $2^{-\Delta \Delta \mathrm{Cq}}$ method (20). Primer sequences were as follows: HIF1- $\alpha$, forward, 5'-GAAGACATCGCGGGGAC-3' and reverse, 5'-TGGCTGCATCTCGAGACTTT-3'; VEGFR-3, forward, 5'-CTCTGCCTGGGACTCCTG-3' and reverse, 5'-GGTGTCGATGACGTGTGACT-3'; VEGF-A, forward, 5'-CCCTGGCTTTACTGCTGTAC-3' and reverse, 5'-TCT GAACAAGGCTCACAGTG-3'; VEGF-C, forward, 5'-AGT GTCAGGCAGCGAACAAGA-3' and reverse, 5'-CTTCCT GAGCCAGGCATCTG-3'; sonic hedgehog (SHH), forward, 5'-GAAAGCAGAGAACTCGGTGG-3' and reverse, 5'-GGA AAGTGAGGAAGTCGCTG-3'; transforming growth factor (TGF)- $\beta$, forward, 5 '-AGCAACAATTCCTGG GGTTACCT-3' and reverse. 5'-CGAAGCCCTGATTCCGTCTCC-3'; prospero homeobox protein 1 (Prox1), forward, 5'-TGATCTGAGCAA CTTCCAGG-3' and reverse, 5'-CAA CGATGGGGTCAC CAGTA-3'; lymphatic vessel endothelial hyaluronan receptor 1 (LYVE-1), forward, 5'-AGCCTACAGGCCTCCTTAGC-3' and reverse, 5'-CTCCTGGTCCAAGGCTCTTT-3'; and $\beta$-actin, forward, 5'-AGCGAGCATCCCCCAAAGTT-3' and reverse, 5'-GGGCACGAAGGCTCATCATT-3'.

Western blot analysis. Frozen tissues or cells were washed twice with ice-cold PBS and incubated for $30 \mathrm{~min}$ on ice with radioimmunoprecipitation assay buffer (Thermo Fisher Scientific, Inc., Waltham, MA, USA). The mixture was centrifuged $\left(12,700 \times \mathrm{g} ; 20 \mathrm{~min} ; 4^{\circ} \mathrm{C}\right)$, the supernatant was collected and the protein concentration was determined using a Bradford assay (Bio-Rad Laboratories, Inc., Hercules, CA, USA). Next, $20 \mu \mathrm{g}$ protein were separated on $8 \%$ SDS-PAGE gels and transferred to $0.22 \mu \mathrm{m}$ polyvinylidene difluoride membranes. Following blocking with $5 \%$ non-fat milk in TBS containing $0.1 \%$ Tween-20 (TBST) at $25^{\circ} \mathrm{C}$ for $1 \mathrm{~h}$, primary antibodies for VEGFR-3 (cat. no. ab27278; 1:1,000; Abcam, Cambridge, UK), HIF-1 $\alpha$ (cat. no. 3716S; 1:1,000; Cell Signaling Technology, Inc., Danvers, MA, USA) and $\beta$-actin (cat. no. 4967L; 1:2,000; Cell Signaling Technology, Inc.) were incubated with the membranes overnight at $4^{\circ} \mathrm{C}$. Following washing with TBST (3x), membranes were incubated for $2 \mathrm{~h}$ at $37^{\circ} \mathrm{C}$ with horseradish peroxidase-conjugated secondary antibody to rabbit IgG (cat. no. ab6727; 1:2,000; Abcam). Proteins were detected using the enhanced chemiluminescence detection method (Pierce; Thermo Fisher Scientific, Inc.) and the specific protein bands were detected with the UVP Bio Imaging system (Tanon Science and Technology Co., Ltd., Shanghai, China). The expression of target proteins was quantitatively analyzed using ImageJ (version 1.43; National Institutes of Health, Bethesda, MD, USA). $\beta$-actin was used as the loading control.

Cell transfection. cDNA of HIF-1 $\alpha(2.5 \mu \mathrm{g}$; cat. no. ab185916; Abcam) was cloned into a pCDH-CMV-MCS-EF1-GFP lentivirus vector (GeneChem, Inc., Daejeon, Korea). Prior to viral infection, Lentivirus complex containing $4 \mu \mathrm{g}$ lentiviral plasmid, $4 \mu \mathrm{g}$ each viral packaging vectors (pRRE, pMD2.G and pRSV; GeneChem, Inc.) and $800 \mu \mathrm{l}$ serum-free ECM were added to HLECs $\left(5 \times 10^{6}\right.$ cells/well) cultured in $10 \mathrm{~cm}$ plates. Culture medium was collected and filtered through $0.45 \mu \mathrm{m}$ polyethersulfone filter. Next, $50 \mu \mathrm{l}$ polybrene $(1 \mu \mathrm{g} / \mu \mathrm{l})$ and $1 \mathrm{ml}$ of the viral supernatant containing the plasmids were added, along with fresh media containing $5 \mathrm{ml}$ ECM with $10 \% \mathrm{FBS}$. At $24 \mathrm{~h}$, the medium was changed and at $72 \mathrm{~h}$, GFP expression was observed under a fluorescent microscope (magnification, $\mathrm{x} 100)$. HIF-1 $\alpha$-overexpressing cells were selected by 
Table I. Characteristic of 20 patients with cystic lymphatic malformations.

\begin{tabular}{lllll}
\hline Sex & Age & Location & Histological type & Lymph property \\
\hline Male & 6 months & Neck & Microcystic & Transparent \\
Female & 2 years & Torso & Mixed cystic & Transparent \\
Female & 3 years & Neck & Mixed cystic & Bloody \\
Male & 2 years & Extremity & Macrocystic & Transparent \\
Male & 1 years & Neck & Macrocystic & Transparent \\
Female & 1 years & Neck & Microcystic & Transparent \\
Male & 2 years & Neck & Mixed cystic & Bloody \\
Male & 5 years & Extremity & Macrocystic & Transparent \\
Female & 5 months & Neck & Microcystic & Transparent \\
Male & 16 days & Neck & Macrocystic & Transparent \\
Male & 1 months & Neck & Mixed cystic & Transparent \\
Female & 4 years & Torso & Macrocystic & Bloody \\
Male & 11 months & Extremity & Mixed cystic & Transparent \\
Female & 2 months & Neck & Macrocystic & Bloody \\
Female & 10 months & Extremity & Microcystic & Transparent \\
Female & 4 years & Neck & Macrocystic & Transparent \\
Male & 20 days & Neck & Microcystic & Transparent \\
Male & 6 years & Torso & Mixed cystic & Bloody \\
Female & 3 months & Neck & Mixed cystic & Transparent \\
Male & 2 months & Neck & Macrocystic & Transparent \\
\hline
\end{tabular}

$\mathrm{CO}$, combined operation; SR, surgical resection.

puromycin $(1 \mu \mathrm{g} / \mathrm{ml})$ over 6 days. Lentivirus overexpressing HIF-1 $\alpha$ (GeneChem, Inc.), VEGFR-3 (GeneChem, Inc.) or containing empty vector (GeneChem, Inc.) were cultured using the enhanced infection reagent (cat. no. REVG0002; GeneChem, Inc.) according to the manufacturer's instructions.

HIF-1 $\alpha$ - and VEGFR-3-overexpressing HLECs were seeded at $1 \times 10^{6}$ cells/well into 6-well culture plates in ECM with $10 \%$ FBS. Short interfering (si)RNA against HIF-1 $\alpha$ (si-HIF-1 $\alpha$ ), VEGFR-3 (si-VEGFR-3) and corresponding scramble negative controls (si-NC) were designed and synthesized by Shanghai GenePharma Co., Ltd. (Shanghai, China). Transfections with $50 \mathrm{nM}$ siRNA were performed in using Lipofectamine 2000 (Invitrogen; Thermo Fisher Scientific, Inc.) according to the manufacturer's instructions. Subsequent assays were performed at $48 \mathrm{~h}$ post transfection. RT-qPCR and western blot assays were used to analyze HIF-1 $\alpha$ and VEGFR-3 expression to determine transfection efficiency. siRNA sequences were as follows: si-HIF-1 $\alpha, 5$ '-CAAGUAGCCUCU UUCACAA-3'; si-VEGFR-3, 5'-CGCCCGAGUUCCAGUG GUA-3'; and si-NC, 5'-UUCUCCGAACGUGUCACGU-3'.

The following experimental groups were established: HIF-1 $\alpha$, HLECs overexpressing HIF-1 $\alpha$; VEGFR-3, HLECs overexpressing VEGFR-3; empty vector, HLECs transfected with empty expression vector; HIF-1 $\alpha$ overexpression + VEGFR-3 knockdown, si-VEGFR-3 transfected into HLECs overexpressing HIF-1 $\alpha$; VEGFR-3 overexpression + HIF-1 $\alpha$ knockdown, si-HIF-1 $\alpha$ transfected into HLECs overexpressing VEGFR-3; HIF-1 $\alpha$ knockdown, HLECs transfected with si-HIF-1 $\alpha$; VEGFR-3 knockdown, HLECs transfected with si-VEGFR-3; NC, HLECs transfected with si-NC.
Colony formation and migration assays. To evaluate colony formation, transfected HLECs were seeded at $1 \times 10^{3}$ cells/well into 6-well plates. Plates were kept at $37^{\circ} \mathrm{C}$ in an incubator with $5 \% \mathrm{CO}_{2}$ for 12 days. Next, cells were washed with PBS, fixed with methanol at $37^{\circ} \mathrm{C}$ for $15 \mathrm{~min}$ and stained with $2 \%$ Giemsa stain (Sigma-Aldrich; Merck KGaA) at $37^{\circ} \mathrm{C}$ for $30 \mathrm{~min}$. Positive colonies were photographed and scored under an inverted light microscope (magnification, x100).

To evaluate the migration of cells in vitro, $5 \times 10^{5}$ HLECs from each group were seeded into 35-mm dishes. When cells had spread to $80-90 \%$ of the well surface and formed a monolayer, the well was scratched with a $200-\mu 1$ pipette tip perpendicular to the surface. Cells were washed with PBS twice followed by the addition of fresh media. Pictures were taken at $0,24,48$ and $72 \mathrm{~h}$ using an inverted light microscope (magnification, x100).

Lymphatic tube formation assay. Mixed fibrinogen gel was prepared by combining $500 \mu \mathrm{l}$ human fibrinogen $(3 \mathrm{mg} / \mathrm{ml}$; Beijing Bio-Ekon Biotechnology Co., Ltd., Beijing, China) and $10 \mu$ l human thrombin (50 U/ml in PBS; Sigma-Aldrich; Merck $\mathrm{KGaA}$ ) with $100 \mu \mathrm{l} \mathrm{ECM}$. For gelling, the mixture was incubated at $37^{\circ} \mathrm{C}$ in $5 \% \mathrm{CO}_{2}$ for $30 \mathrm{~min}$. Fibrinogen gel $(0.05 \mathrm{ml} /$ well $)$ was used to coat the walls of 96 -well plates and incubated at $37^{\circ} \mathrm{C}$ for $1 \mathrm{~h}$. Transfected HLECs $\left(1 \times 10^{5} / \mathrm{ml} ; 100 \mu \mathrm{l} /\right.$ well $)$ from the HIF-1 $\alpha$, empty vector, HIF-1 $\alpha$ overexpression + VEGFR-3 knockdown, HIF-1 $\alpha$ knockdown or NC groups were seeded on the gel and cultured in an incubator with $5 \% \mathrm{CO}_{2}$ at $37^{\circ} \mathrm{C}$. Media was changed every 4 days. Following 10 days, cells were observed by inverted phase-contrast light microscopy (magnification, x100). Lymphatic tube formation was determined using morphological 
A
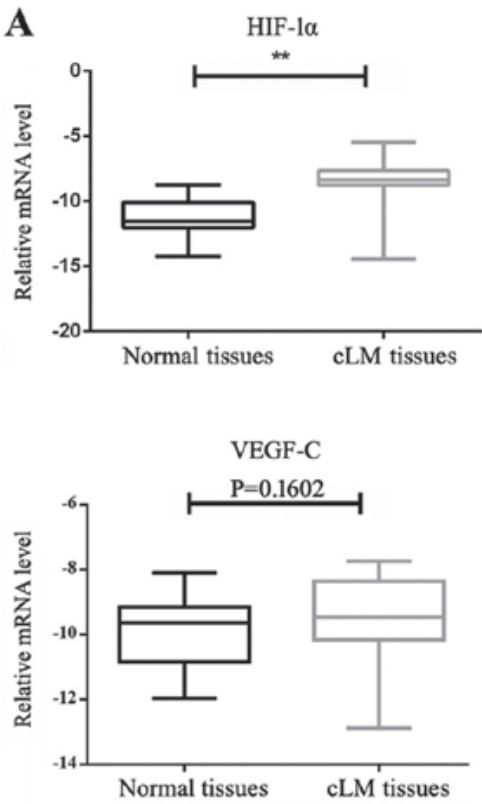
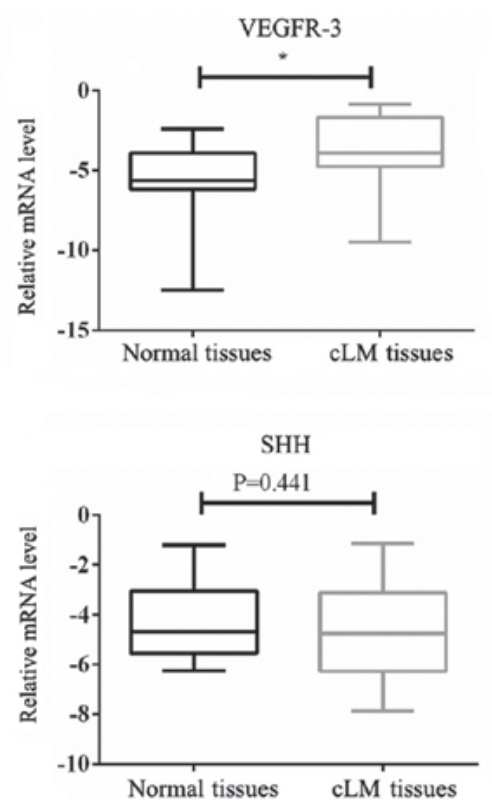
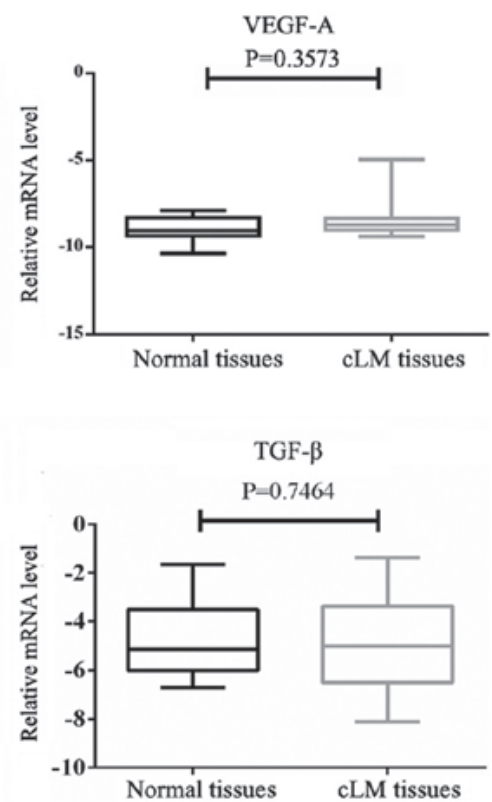

B

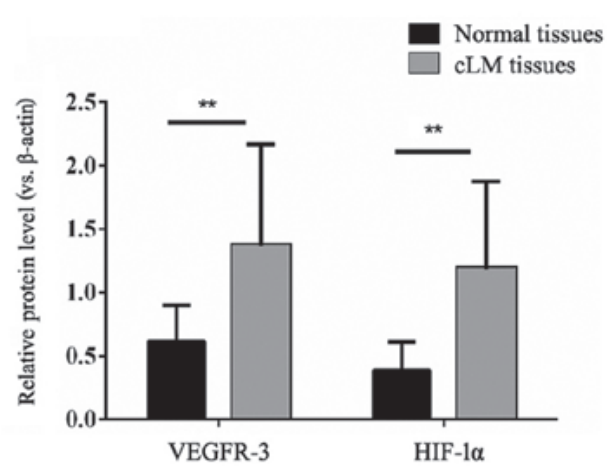

C

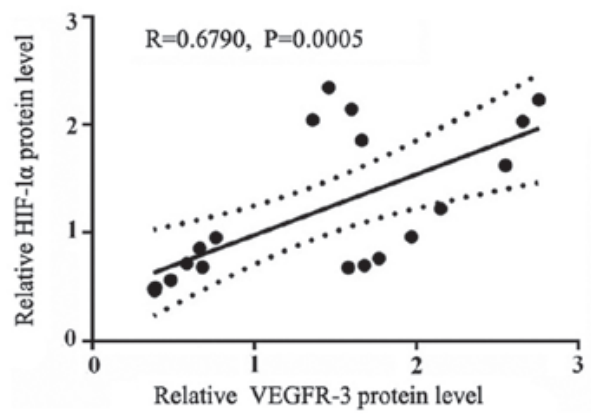

Figure 1. HIF-1 $\alpha$ and VEGFR-3 levels are increased in cLM specimens. (A) HIF-1 $\alpha$ and VEGFR-3 mRNA levels were determined for cLM and adjacent control tissues $(\mathrm{n}=20)$. mRNA expression of VEGF-A, VEGF-C, SHH and TGF- $\beta$ was further evaluated. (B) HIF-1 $\alpha$ and VEGFR-3 protein expression were determined in cLM and control tissues. (C) Correlation analysis of HIF- $1 \alpha$ and VEGFR-3 protein expression. Experiments were repeated $\geq 3$ times and data are presented as mean \pm standard deviation. ${ }^{*} \mathrm{P}<0.05$ and ${ }^{* *} \mathrm{P}<0.01$ vs. normal tissues. HIF-1 $\alpha$, hypoxia-inducible factor-1 $\alpha$; VEGF, vascular endothelial growth factor; cLM, cystic lymphatic malformations; SHH, sonic hedgehog; TGF, transforming growth factor.

characteristics and the number of lymphatic tubes observed in three random microscopic fields per well. Western blot assays were performed to analyze HIF-1 $\alpha$ and VEGFR-3 expression at days 4, 6 and 10 during HLECs lymphangiogenesis.

Determination of adenosine triphosphate (ATP) content. ATP levels in transfected HLECs from different groups were determined at $48 \mathrm{~h}$ post transfection using the Enhanced ATP Assay kit (cat. no. S0027; Beyotime Institute of Biotechnology, Haimen, China) according to the manufacturer's instructions. Total ATP levels (range, 0.1-10 $\mu \mathrm{M}$ ) were calculated from the luminescence signals and results are presented in arbitrary units.

Statistical analysis. Experiments were repeated $\geq 3$ times and data are presented as mean \pm standard deviation. SPSS 19.0 (IBM Corp., Armonk, NY, USA) and GraphPad Prism 6.0 (GraphPad Software, Inc., La Jolla, CA, USA) were used for statistical analyses. Statistical differences were evaluated using the Student's t-test or one-way analysis of variance followed by
Student-Newman-Keuls post-hoc tests. Correlation between HIF-1 $\alpha$ and VEGFR-3 protein expression in CLM tissues was determined using Pearson analysis. $\mathrm{P}<0.05$ was considered to indicate a statistically significant difference.

\section{Results}

HIF-1 $\alpha$ and VEGFR-3 are overexpressed in cLM specimen. mRNA expression of HIF-1 $\alpha$, VEGFR-3, VEGF-A, VEGF-C, SHH and TGF- $\beta$ in cLM and matched cLM-adjacent healthy tissues were determined by RT-qPCR. As presented in Fig. 1A, HIF- $1 \alpha$ and VEGFR-3 mRNA levels were significantly upregulated in cLM tissues compared with the adjacent tissues $(\mathrm{P}<0.05)$. There were no significant differences in VEGF-A, VEGF-C, SHH and TGF- $\beta$ mRNA expression between cLM and matched healthy tissues. Significantly increased HIF-1 $\alpha$ and VEGFR-3 protein levels were observed in cLM tissues compared with matched healthy tissues $(\mathrm{P}<0.01$; Fig. 1B). Furthermore, analysis revealed a strong positive correlation between HIF-1 $\alpha$ and VEGFR-3 protein expression in cLM 
A

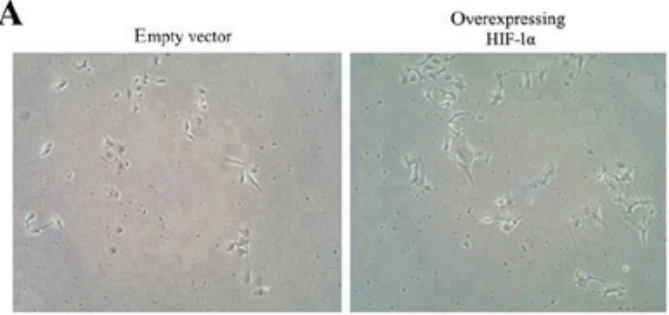

C

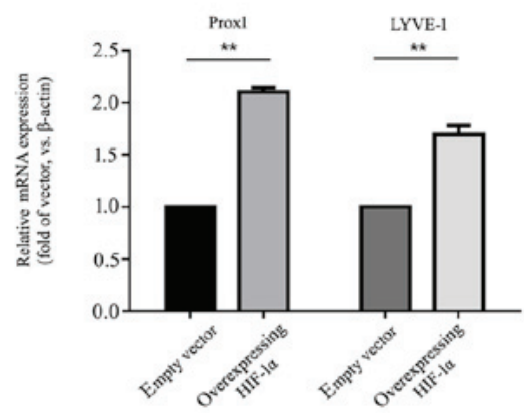

B
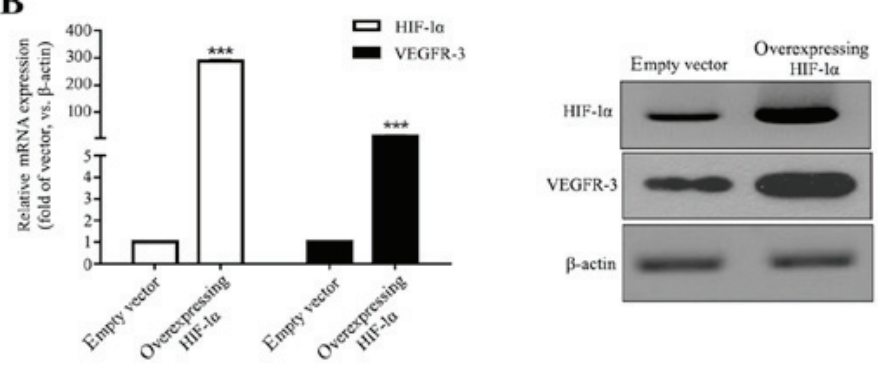

D

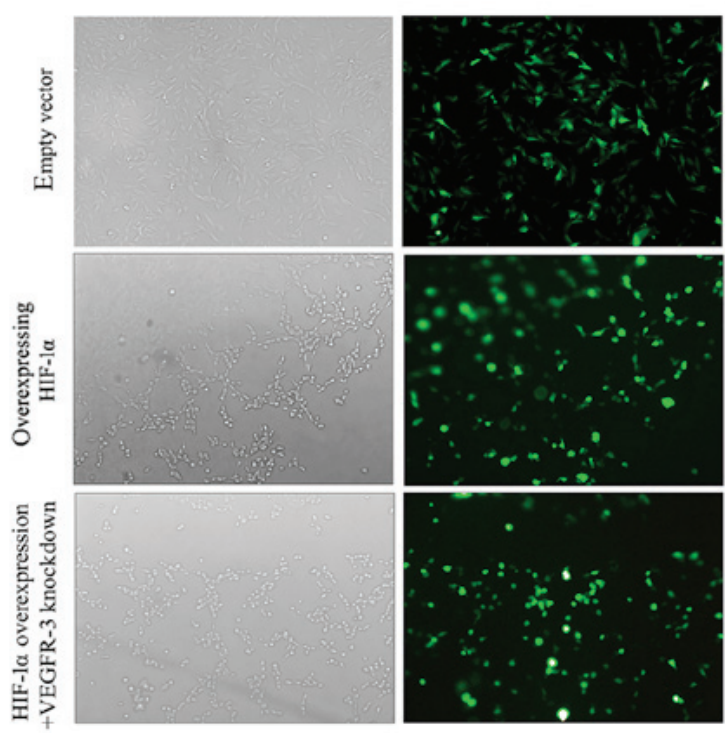

Figure 2. Characterization of HIF-1 $\alpha$-overexpressing HLECs. (A) Morphology of HIF-1 $\alpha$-overexpressing and empty vector-transfected HLECs (magnification, x100). (B) HIF-1 $\alpha$ and VEGFR-3 mRNA and protein levels and (C) Prox1 and LYVE-1 mRNA expression in HIF-1 $\alpha$-overexpressing and empty vector-transfected HLECs. (D) HLECs transfected with various lentiviral vectors were observed by fluorescence microscopy at $72 \mathrm{~h}$ post transfection (magnification, $\mathrm{x} 100$ ). Experiments were repeated $\geq 3$ times with similar results and data are presented as mean \pm standard deviation. ${ }^{* *} \mathrm{P}<0.01$ and ${ }^{* * * *} \mathrm{P}<0.001$ vs. empty vector. HLEC, human lymphatic endothelial cell; HIF-1 $\alpha$, hypoxia-inducible factor-1 $\alpha$; VEGF, vascular endothelial growth factor; Prox1, prospero homeobox protein 1; LYVE-1, lymphatic vessel endothelial hyaluronan receptor 1.

tissues, with a Pearson's correlation coefficient of 0.6790 ( $\mathrm{P}=0.0005$; Fig. 1C).

Characterization of HIF-1 $\alpha$-overexpressing HLECs. To investigate the biological role of HIF- $1 \alpha$ in the development and progression of lymphatic malformation in HLECs, cells overexpressing HIF-1 $\alpha$ were created by lentiviral infection. HIF-1 $\alpha$-overexpressing HLECs maintained the morphology of normal endothelial cells; however, they appeared multi-angular and irregular compared with empty vector-transfected HLECs (magnification, x100; Fig. 2A). RT-qPCR and western blot were used to determine HIF-1 $\alpha$ and VEGFR-3 expression in HIF-1 $\alpha$-overexpressing HLECs at $72 \mathrm{~h}$ post transfection (Fig. 2B). It was observed that in HIF-1 $\alpha$-overexpressing HLECs HIF- $1 \alpha$ and VEGFR-3 mRNA levels were significantly increased compared with the empty vector control $(\mathrm{P}<0.001)$ and protein expression was markedly increased in the HIF-1 $\alpha$-overexpressing HLECs. HIF- $1 \alpha$ overexpression significantly increased expression of lymphatic endothelial markers Prox1 and LYVE-1 in HLECs compared with the empty vector control $(\mathrm{P}<0.01 ;$ Fig. $2 \mathrm{C})$. Fluorescence microscopy to evaluate the GFP content revealed that $>80 \%$ of HLECs in the empty vector, the HIF- $1 \alpha$ and the HIF- $1 \alpha$ overexpression + VEGFR-3 knockdown groups expressed GFP following transfection, indicating a successfully transfection (Fig. 2D).

Overexpression of HIF-1 $\alpha$ promotes colony formation and migration of HLECs. To determine the role of HIF-1 $\alpha$ in cLM progression, the impact of HIF-1 $\alpha$ on colony formation and migration was examined in vitro. RT-qPCR and western blot assays confirmed a significant increase in HIF-1 $\alpha$ mRNA and a marked increase in protein levels in HIF-1 $\alpha$-overexpressing HLECs compared with the empty control $(\mathrm{P}<0.001$; Fig. 3A and B). The significantly increased HIF- $1 \alpha$ mRNA and markedly increased protein levels were maintained in the HIF-1 $\alpha$ overexpression + VEGFR-3 knockdown group compared with the empty vector control $(\mathrm{P}<0.001$; Fig. $3 \mathrm{~A}$ and $\mathrm{B})$. No significant difference in HIF-1 $\alpha$ levels was determined between the HIF-1 $\alpha$ and HIF-1 $\alpha$ overexpression + VEGFR-3 knockdown groups $(\mathrm{P}>0.05)$. VEGFR-3 mRNA levels were significantly increased and protein levels were markedly increased in the HIF-1 $\alpha$ group compared with the empty vector group $(\mathrm{P}<0.001$; Fig. $3 \mathrm{~A}$ and $\mathrm{B})$. For the HIF-1a overexpression + VEGFR-3 knockdown group, no significant difference was observed in VEGFR-3 expression compared with the empty vector group $(\mathrm{P}>0.05$; Fig. $3 \mathrm{~A}$ and $\mathrm{B})$. VEGFR-3 mRNA levels were significantly $(\mathrm{P}<0.001$; Fig. 3A) 
A

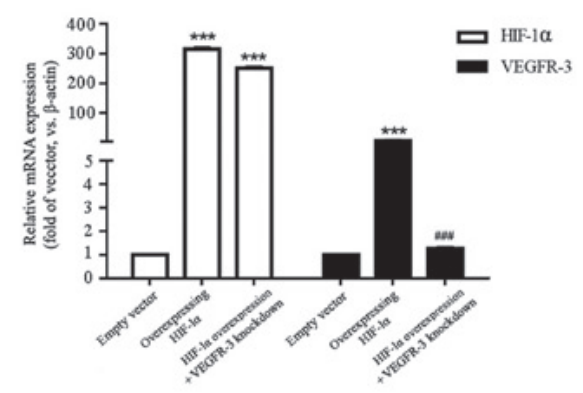

C
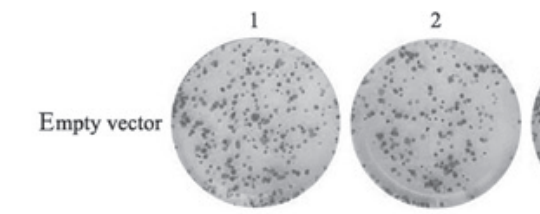

3

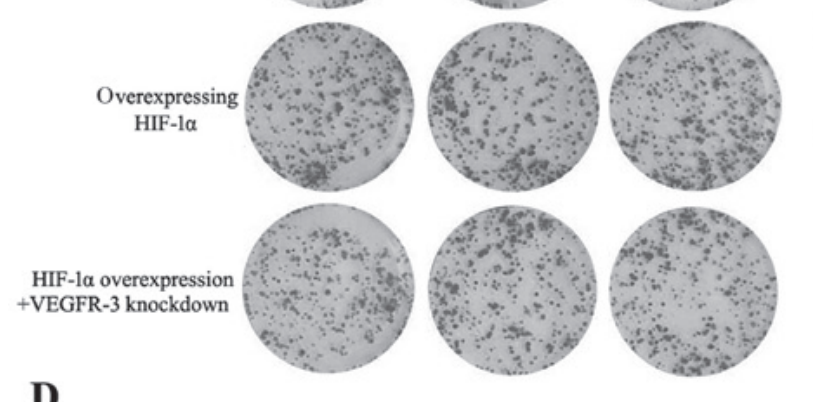

D

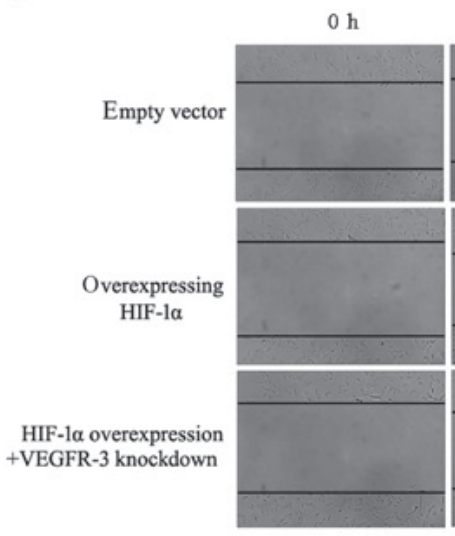

$24 \mathrm{~h}$

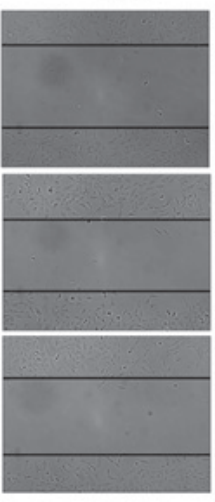

B

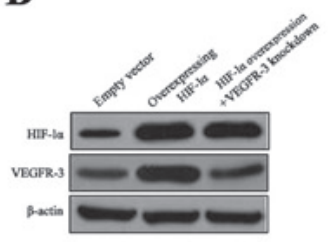

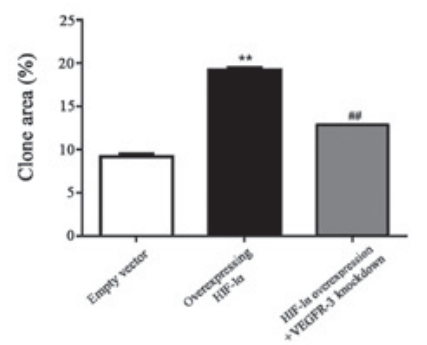

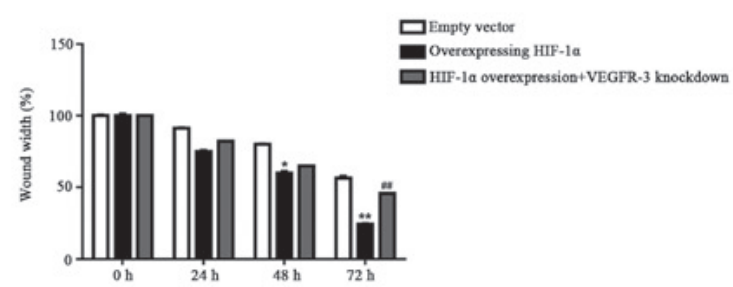

Figure 3. Effects of HIF-1 $\alpha$ overexpression on HLEC colony formation and migration in vitro. (A) Transfection efficiency in HLECs was determined by reverse transcription-quantitative polymerase chain reaction for cells transfected with empty vector, an HIF-1 $\alpha$ overexpression vector or an HIF-1 $\alpha$ overexpression vector and short interfering RNA targeting VEGFR-3. (B) Protein levels of HIF-1 $\alpha$ and VEGFR-3, (C) HLEC colony formation and (D) wound-healing assays (magnification, x100) for the empty vector, the HIF-1 $\alpha$ overexpression and the HIF-1 $\alpha$ overexpression + VEGFR-3 knockdown groups. Experiments were repeated $\geq 3$ times with similar results and data are presented as mean \pm standard deviation. ${ }^{*} \mathrm{P}<0.05,{ }^{* *} \mathrm{P}<0.01$ and ${ }^{* * *} \mathrm{P}<0.001$ vs. empty vector; ${ }^{\# \#} \mathrm{P}<0.01$ and

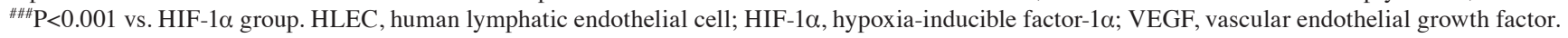

and protein levels were markedly (Fig. 3B) decreased in the HIF-1 $\alpha$ overexpression + VEGFR-3 knockdown group compared with the HIF-1 $\alpha$ group.

Overexpression of HIF-1 $\alpha$ enhanced colony formation, as presented by the significant increase in clone area compared with the empty vector control $(\mathrm{P}<0.01 ;$ Fig. $3 \mathrm{C})$. Interestingly, in the HIF-1 $\alpha$ overexpression + VEGFR-3 knockdown group, there was no significant difference in clone area compared with the empty vector group ( $\mathrm{P}>0.05$; Fig. $3 \mathrm{C}$ ). The clone area in HIF-1 $\alpha$ overexpression + VEGFR-3 knockdown group was significantly decreased compared with the HIF- $1 \alpha$ group $(\mathrm{P}<0.01$; Fig. 3C).

Furthermore, the effect of HIF-1 $\alpha$ on HLEC migration was examined using wound-healing assays. Overexpression of 
$\mathbf{A}$

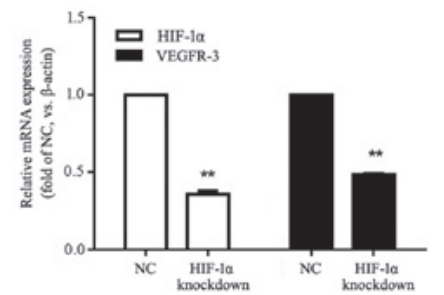

B

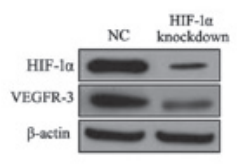

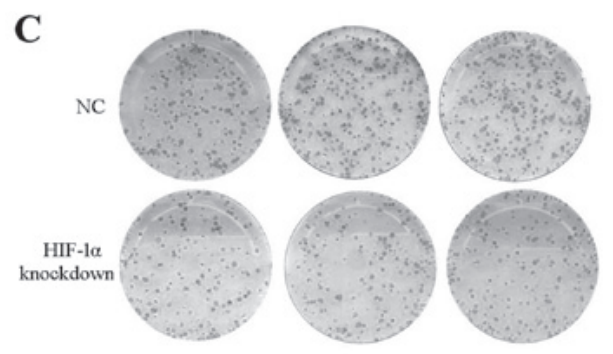

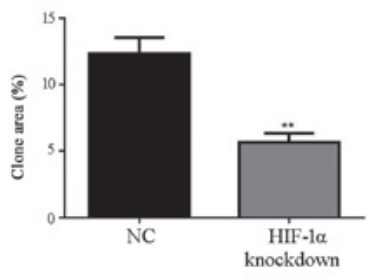

D
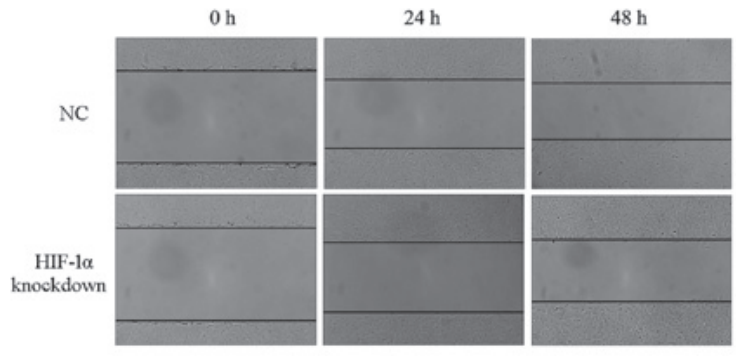

$72 \mathrm{~h}$
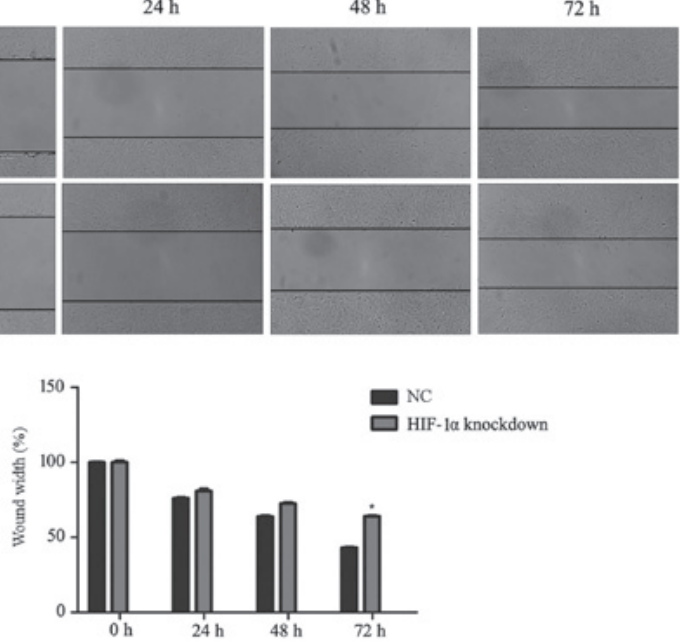

Figure 4. Effects of HIF-1 $\alpha$ knockdown on HLEC colony formation and migration. (A) Relative mRNA expression of HIF-1 $\alpha$ and VEGFR-3 in HLECs transfected with and short interfering RNA targeting HIF-1 $\alpha$. (B) HIF-1 $\alpha$ and VEGFR-3 protein expression, (C) colony formation and (D) wound-healing assays (magnification, x100) for HIF-1 $\alpha$ knockdown and NC groups. Experiments were repeated $\geq 3$ times with similar results and data are presented as mean \pm standard deviation. ${ }^{*} \mathrm{P}<0.05$ and ${ }^{* *} \mathrm{P}<0.01$ vs. NC. HLEC, human lymphatic endothelial cell; HIF-1 $\alpha$, hypoxia-inducible factor-1 $\alpha$; VEGF, vascular endothelial growth factor; NC, negative control.

HIF-1 $\alpha$ significantly increased cell migration at 48 and $72 \mathrm{~h}$ compared with empty vector group $(\mathrm{P}<0.05$ and $\mathrm{P}<0.01$, respectively; Fig. 3D). As described above, in the HIF-1 $\alpha$ overexpression + VEGFR-3 knockdown group, no significant difference in cell migration was observed compared with the empty vector control ( $\mathrm{P}>0.05$; Fig. 3D). Cell migration in the HIF-1 $\alpha$ overexpression + VEGFR-3 knockdown group was significantly decreased at $72 \mathrm{~h}$ compared with the HIF-1 $\alpha$ group $(\mathrm{P}<0.01$; Fig. 3D). These results suggested that overexpression of HIF- $1 \alpha$ promoted HLEC colony formation and migration by upregulating VEGFR-3.

HIF-1a knockdown inhibits HLEC colony formation and migration. HLECs were transfected with HIF-1 $\alpha$ siRNA to observe knockout effects on colony formation and migration. Transfection success was determined by RT-qPCR and western blot, demonstrating significantly decreased mRNA and markedly decreased protein levels of HIF-1 $\alpha$ and VEGFR-3 in the HIF-1 $\alpha$ knockdown group compared with the NC group $(\mathrm{P}<0.01$; Fig. $4 \mathrm{~A}$ and $\mathrm{B})$. HIF-1 $\alpha$ knockdown significantly decreased clone area compared with the NC group $(\mathrm{P}<0.01$; Fig. 4C). Cell migration was significantly reduced at $72 \mathrm{~h}$ in the HIF-1 $\alpha$ knockdown compared with the NC group $(\mathrm{P}<0.05$; Fig. 4D). These results indicated that HIF-1 $\alpha$ knockdown reduced HLEC colony formation and migration.

Overexpression of VEGFR-3 promotes HLEC colony formation and migration. VEGFR-3 overexpression was confirmed by RT-qPCR and western blot assays, where mRNA levels were significantly and protein levels were markedly increased compared with the empty vector control $(\mathrm{P}<0.001$; Fig. 5A and $\mathrm{B})$. There was no significant difference in VEGFR-3 mRNA expression in the VEGFR-3 overexpression $+\mathrm{HIF}-1 \alpha$ knockdown group compared with empty vector group ( $\mathrm{P}>0.05$; Fig. 5A). HIF-1 $\alpha$ mRNA and protein levels were unaffected by VEGFR-3 overexpression; however, mRNA levels were significantly and protein levels markedly reduced in the VEGFR-3 overexpression + HIF-1 $\alpha$ knockdown group compared with the empty vector control 
A

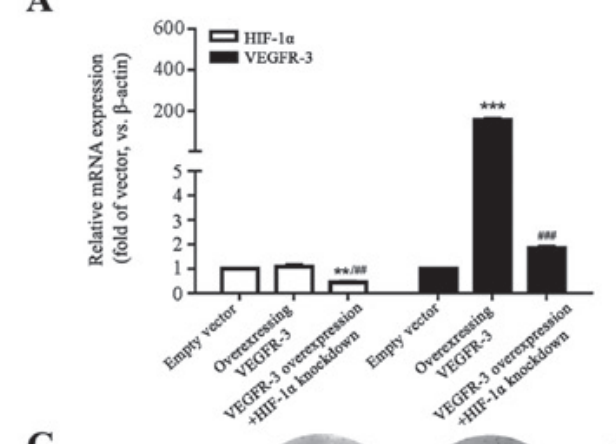

C

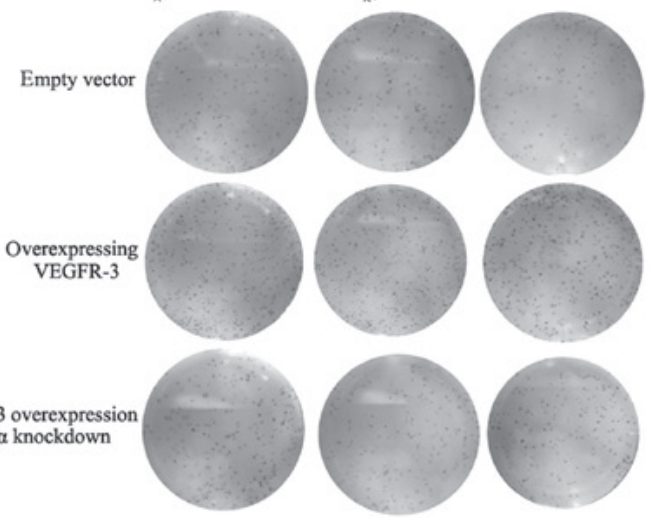

D

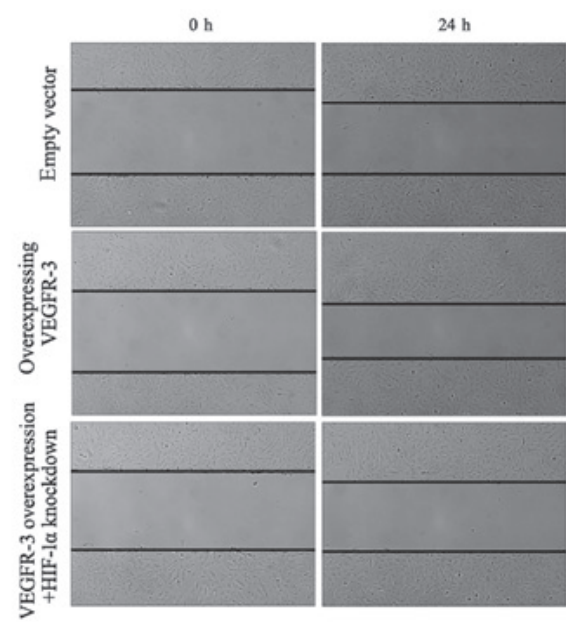

B
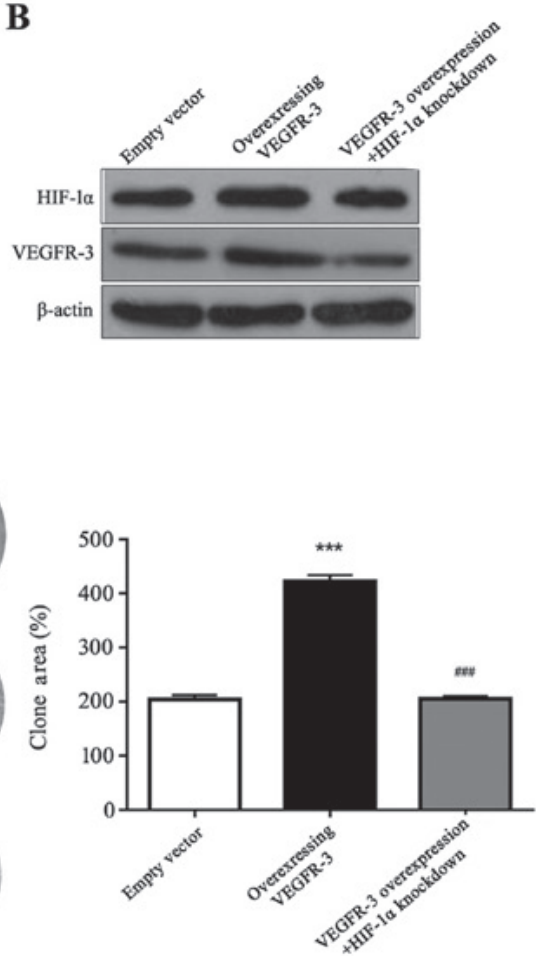

48

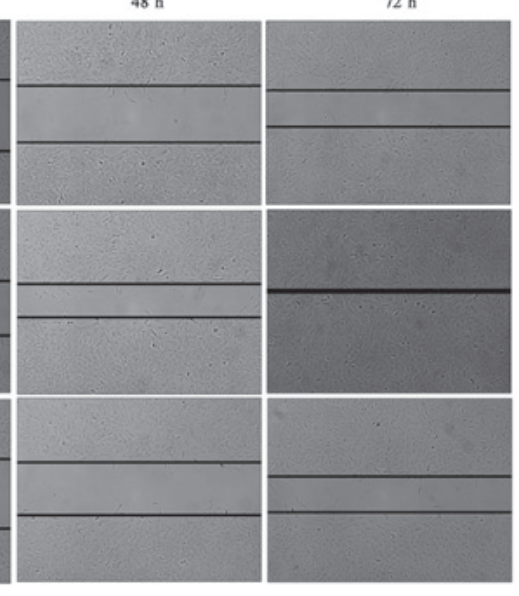

$\square$ Empty vector

Overexpressing VEGFR-3

VEGFR-3 overexpression+HIF-1 $\alpha$ knockdown

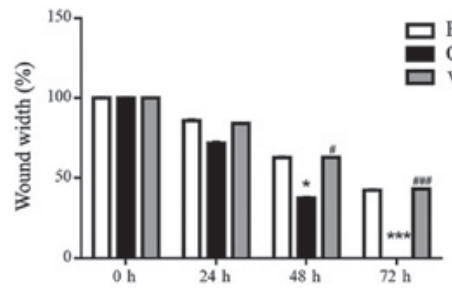

Figure 5. Effects of VEGFR-3 overexpression on HLEC colony formation and migration. (A) Transfection efficiency in HLECs was determined by reverse transcription-quantitative polymerase chain reaction for cells transfected with empty vector, VEGFR-3 or VEGFR-3 + short interfering RNA targeting HIF-1 $\alpha$. (B) Protein levels of HIF-1 $\alpha$ and VEGFR-3, (C) colony formation and (D) wound-healing assays (magnification, x100) for the empty vector, the VEGFR-3 overexpression and the VEGFR-3 overexpression + HIF-1 $\alpha$ knockdown groups. Experiments were repeated $\geq 3$ times with similar results and data are presented as mean \pm standard deviation. ${ }^{*} \mathrm{P}<0.05,{ }^{* *} \mathrm{P}<0.01$ and ${ }^{* * *} \mathrm{P}<0.001$ vs. empty vector; ${ }^{\#} \mathrm{P}<0.05,{ }^{\# \#} \mathrm{P}<0.01$ and ${ }^{\# \# \#} \mathrm{P}<0.001$ vs. VEGFR-3 group. HLEC, human lymphatic endothelial cell; HIF-1 $\alpha$, hypoxia-inducible factor-1 $\alpha$; VEGF, vascular endothelial growth factor.

(P<0.01; Fig. 5A and B). HIF-1 $\alpha$ and VEGFR-3 mRNA levels were significantly and protein levels were markedly decreased in theVEGFR-3 overexpression + HIF-1 $\alpha$ knockdown group compared with the VEGFR-3 group $(\mathrm{P}<0.01$ and $\mathrm{P}<0.001$, respectively; Fig. 5A and B).
Colony formation and wound-healing assays were performed to investigate functions of VEGFR-3 in vitro. As presented in Fig. 5C, VEGFR-3 overexpression in HLECs significantly increased colony formation compared with the empty control group $(\mathrm{P}<0.001)$. Additionally, 


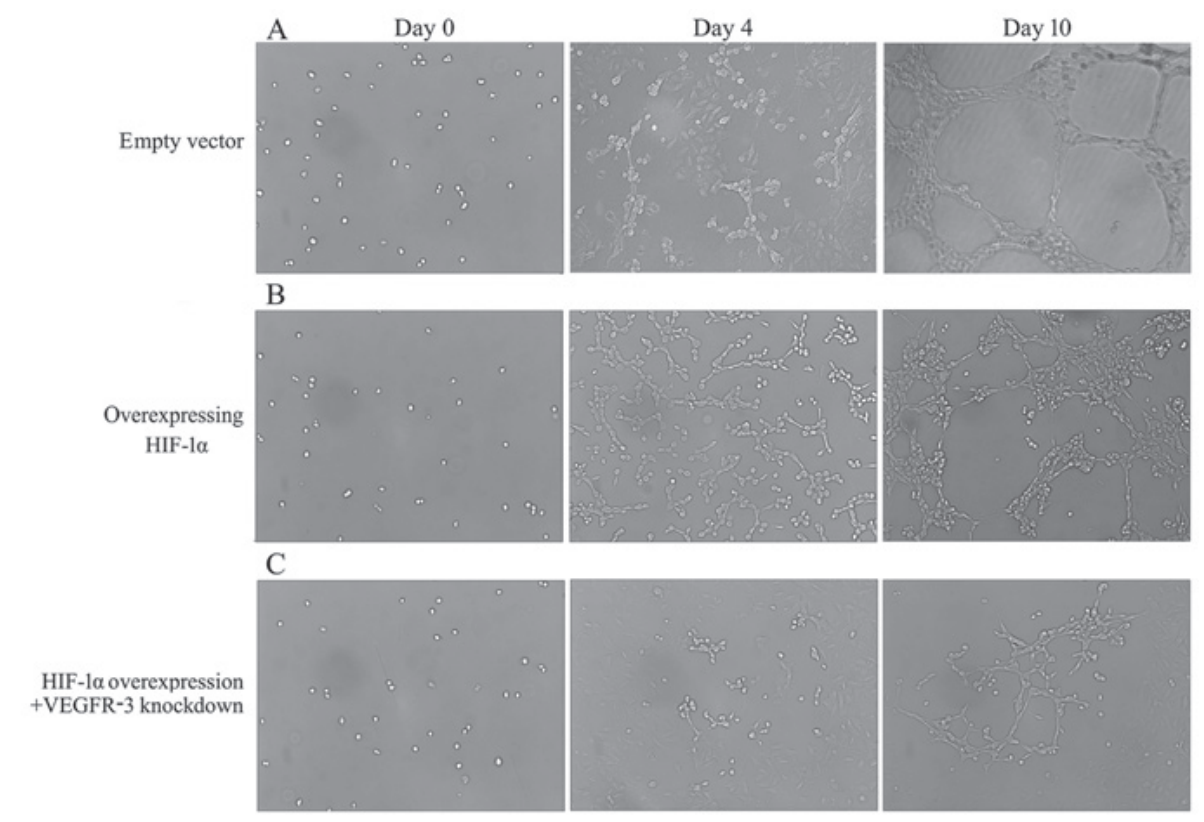

Figure 6. HIF-1 $\alpha$ overexpression induces lymphatic tube malformation in HLECs during lymphangiogenesis. (A) HLECs transfected with empty vector on days 0, 4 and 10. (B) HIF-1 $\alpha$-overexpressing HLECs on days 0, 4 and 10. (C) HLECs of the HIF-1 $\alpha$ overexpression + VEGFR-3 knockdown group on days 0, 4 and 10 (magnification, $x 100$ ). Experiments were repeated $\geq 3$ times with similar results. HLEC, human lymphatic endothelial cell; HIF-1 $\alpha$, hypoxia-inducible factor-1 $\alpha$; VEGF, vascular endothelial growth factor.

clone area did not change significantly in the VEGFR-3 overexpression + HIF-1 $\alpha$ knockdown group compared with the empty vector control $(\mathrm{P}>0.05$; Fig. $5 \mathrm{C})$. The clone area in the VEGFR-3 overexpression + HIF-1 $\alpha$ knockdown group was significantly decreased compared with the VEGFR-3 group ( $\mathrm{P}<0.001$; Fig. 5C).

VEGFR-3 overexpression significantly promoted HLEC migration compared with the empty vector control at 48 and $72 \mathrm{~h}(\mathrm{P}<0.05$ and $\mathrm{P}<0.001$, respectively; Fig. 5D) and no significant differences were observed between the VEGFR-3 overexpression + HIF-1 $\alpha$ knockdown and the empty vector control group ( $\mathrm{P}>0.05$; Fig. 5D). Cell migration in the VEGFR-3 overexpression + HIF-1 $\alpha$ knockdown group was significantly decreased at 48 and $72 \mathrm{~h}$ compared with the VEGFR-3 group ( $\mathrm{P}<0.05$ and $\mathrm{P}<0.001$, respectively; Fig. 5D). These results indicated that VEGFR-3 levels that were regulated by HIF-1 $\alpha$ expression promoted HLEC colony formation and migration.

HIF-1 $\alpha$ overexpression induces lymphatic tube malformation in HLECs. The process of lymphangiogenesis was observed in vitro over 10 days. As presented in Fig. 6, following seeding of cells on the mixed fibrinogen gel for 4 days, HLECs in the HIF-1 $\alpha$ group formed extensive tubular structures (Fig. 6B) and cells in empty vector group were observed to form cell clusters (Fig. 6A). Compared with the empty vector group, fewer cell clusters were observed on day 4 in the HIF-1 $\alpha$ overexpression + VEGFR-3 knockdown group (Fig. 6C).

Malformations in the structure and shape of the lymphatic capillary-type tubules were observed with various dilatations in the HIF-1 $\alpha$ group at day 10 (Fig. 6B). Normal and typical lymphatic tube structures were exhibited by the empty vector group at the same time (Fig. 6A). Cells in the HIF-1 $\alpha$ overexpression + VEGFR-3 knockdown group exhibited decreased formation of tubule walls and a lower density of lymphatic tube structures compared with the empty vector and the HIF- $1 \alpha$ groups (Fig. 6C). HIF- $1 \alpha$ overexpression induced lymphatic tube malformation in HLECs, potentially by upregulating VEGFR-3 expression.

HIF-1 $\alpha$ knockdown inhibits lymphatic tube formation in HLECs. To further investigate the role of HIF-1 $\alpha$ in lymphatic tube formation, HIF-1 $\alpha$ knockdown cells were observed. Cell clusters observed in the HIF-1 $\alpha$ knockdown were decreased in size compared with the $\mathrm{NC}$ group at day 4 (Fig. 7A and B). HIF-1 $\alpha$ knockdown cells presented several cell clusters without signs for the formation of lymphatic tubes at day 10, while typical but small tube structures were observed in $\mathrm{NC}$ group (Fig. 7A and B). Compared with the empty vector control, smaller dilation of lymphatic tubes in the NC group may be caused by si-NC transfection. These findings indicated that the HIF-1 $\alpha$ knockdown in HLECs resulted in the loss of the ability to form lymphatic tubes.

HIF-1 $\alpha$ upregulates expression of VEGFR-3 and lymphatic endothelial markers during lymphatic tube formation. To investigate the role of HIF- $1 \alpha$ in HLEC proliferation during lymphatic tube formation, an enhanced ATP assay was performed at $48 \mathrm{~h}$ post transfection. In HIF-1 $\alpha$-overexpressing HLECs with or without VEGFR-3 knockdown, ATP levels increased significantly compared with empty vector group $(\mathrm{P}<0.01$ and $\mathrm{P}<0.05$, respectively; Fig. 8A). ATP levels in HIF-1 $\alpha$ overexpression + VEGFR-3 knockdown group were significantly decreased compared with the HIF- $1 \alpha$ group $(\mathrm{P}<0.05$; Fig. $8 \mathrm{~A})$. In the HIF- $1 \alpha$ knockdown group, ATP levels were significantly decreased compared with the NC group (P<0.05; Fig. 8A). VEGFR-3 and HIF-1 $\alpha$ protein 

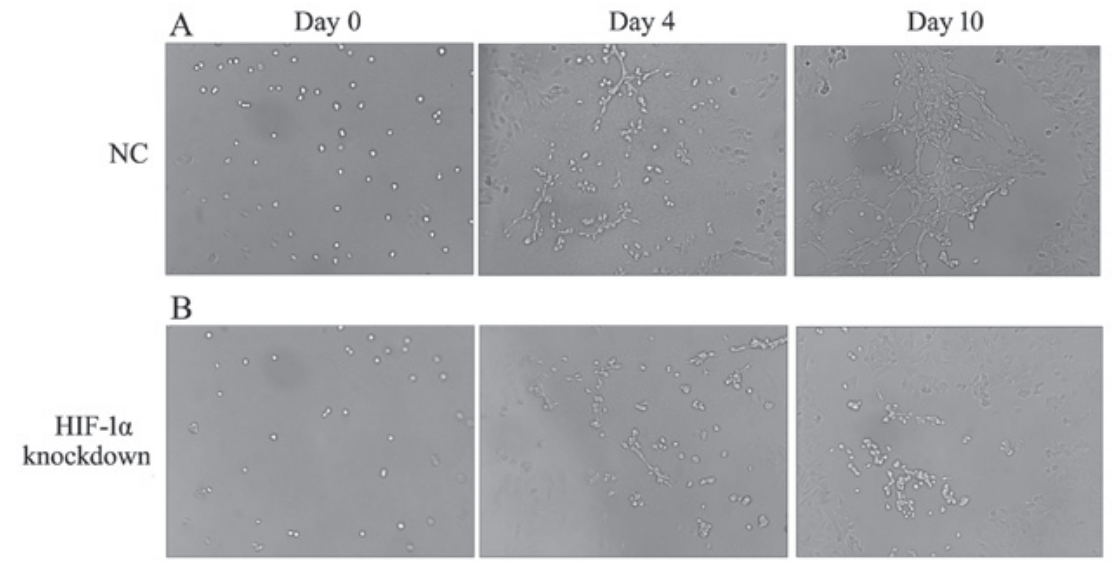

Figure 7. Effect of HIF-1 $\alpha$ knockdown on tube formation in HLECs during lymphangiogenesis. (A) HLECs transfected with NC on days 0,4 and 10 . (B) Cell in the HIF-1 $\alpha$ knockdown group on days 0, 4 and 10 (magnification, x100). Experiments were repeated $\geq 3$ times with similar results. HLEC, human lymphatic endothelial cell; HIF-1 $\alpha$, hypoxia-inducible factor-1 $\alpha$; NC, negative control.

$\mathbf{A}$

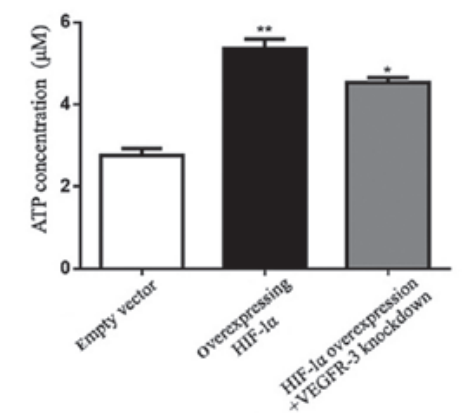

C

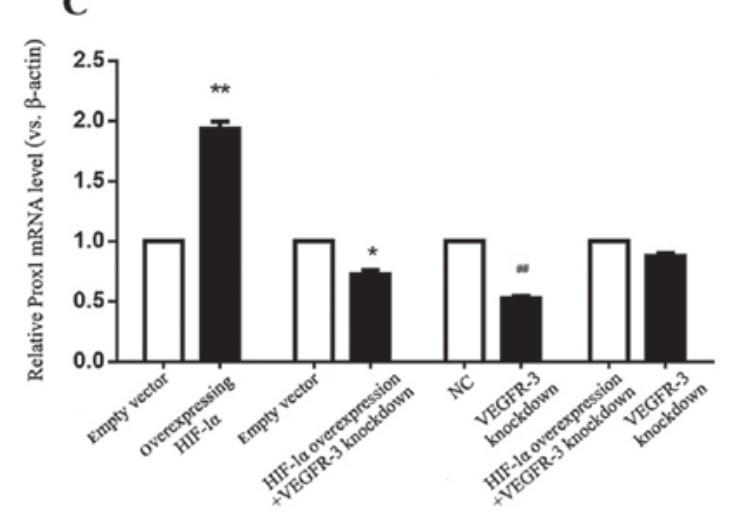

B
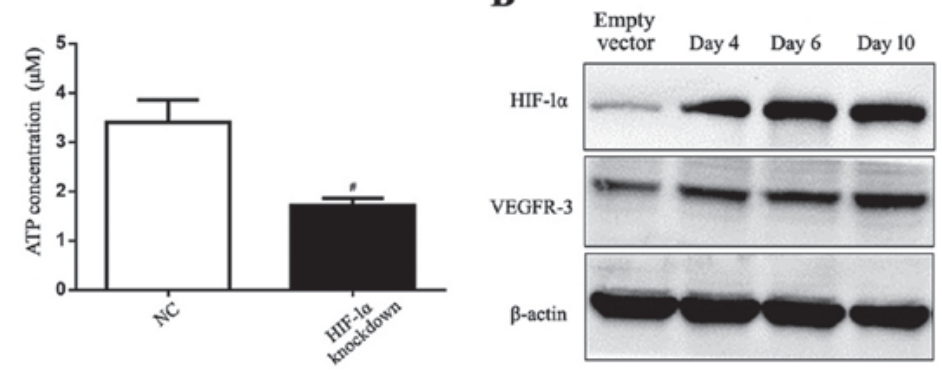

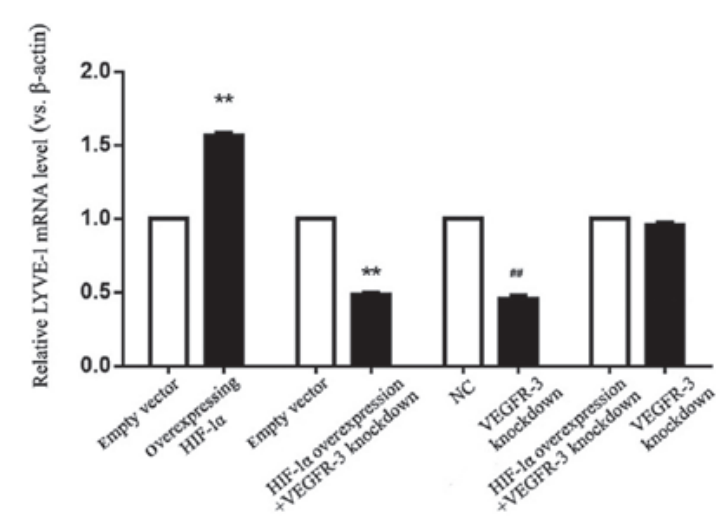

Figure 8. Effects of HIF-1 $\alpha$ overexpression on VEGFR-3 protein and Prox1 and LYVE-1 mRNA levels during lymphangiogenesis. (A) ATP concentration in HLECs of the empty vector, the HIF-1 $\alpha$ overexpression and the HIF-1 $\alpha$ overexpression + VEGFR-3 knockdown groups and the NC and the HIF-1 $\alpha$ knockdown groups during lymphangiogenesis. (B) VEGFR-3 protein levels in HIF-1 $\alpha$-overexpressing HLECs during tube formation compared with the empty vector group on day 10. (C) Relative Prox 1 and LYVE-1 protein expression in HLECs overexpressing HIF-1 $\alpha$, HIF-1 $\alpha$ overexpression + VEGFR-3 knockdown and VEGFR-3 knockdown groups with respective controls. Experiments were repeated $\geq 3$ times with similar results and data are presented as mean \pm standard deviation. ${ }^{*} \mathrm{P}<0.05$ and ${ }^{* *} \mathrm{P}<0.01$ vs. empty vector; ${ }^{\#} \mathrm{P}<0.05$ and ${ }^{\# \#} \mathrm{P}<0.01$ vs. NC. HLEC, human lymphatic endothelial cell; HIF-1 $\alpha$, hypoxia-inducible factor-1 $\alpha$; NC, negative control; Prox1, prospero homeobox protein 1; lymphatic vessel endothelial hyaluronan receptor 1.

expression was determined on days 4,6 and 10 during HLEC lymphangiogenesis. As presented in Fig. 8B, HIF-1 $\alpha$ overexpression increased VEGFR-3 protein expression in HLECs during lymphatic tube formation compared with empty vector group (Fig. 8B). To assess the impact of HIF-1 $\alpha$ on the expression of lymphatic endothelial markers, mRNA levels of Prox 1 and LYVE-1 at day 10 during lymphangiogenesis were determined. Prox1 and LYVE-1 mRNA levels were significantly increased in the HIF-1 $\alpha$ group compared with the empty vector control $(\mathrm{P}<0.01$; Fig. $8 \mathrm{C})$. Significantly decreased Prox 1 and LYVE-1 expression was observed for the HIF-1 $\alpha$ overexpression + VEGFR-3 knockdown $(\mathrm{P}<0.05$ and $\mathrm{P}<0.01$, respectively) and the VEGFR-3 knockdown groups compared with the respective empty vector and $\mathrm{NC}$ controls $(\mathrm{P}<0.01$; Fig. 8C). These findings demonstrated that HIF-1 $\alpha$ promoted HLEC proliferation and induced the malformation 
of lymphatic tubes by upregulating VEGFR-3 expression and lymphatic endothelial markers in vitro.

\section{Discussion}

According to the 2018 International Society for the Study of Vascular Anomalies classification of vascular anomalies, cLM is a primary type of lymphatic anomaly that includes generalized lymphatic anomaly, lymphatic malformations in Gorham-Stout disease, primary lymphedema and several other subtypes (21). The lymphatic channels of cLM dilate to various degrees and are lined by endothelial cells with normal lymphatic phenotype (1). The pathogenesis of cLM remains unclear and molecular events leading to tubular malformation in lymphatic endothelial cells are not fully understood, preventing improvements in clinical prevention and treatment.

HIF- $1 \alpha$ mediates transcriptional activation of lymphangiogenesis via regulation of signaling pathways, including VEGF-C, SHH and TGF- $\beta$ in certain human tumors $(22,23)$. Previous studies demonstrated that HIF-1 $\alpha$ inhibition impaired gastric cancer growth and vascular endothelial cells in angiogenesis (24), while hypoxia-dependent activation of the nuclear factor- $\kappa \mathrm{B} / \mathrm{HIF}-1 \alpha / \mathrm{VEGF}$ signaling pathway contributed to gastric cancer promotion via enhancing angiogenesis (25). HIF-1 $\alpha$ and VEGF expression have further been suggested to function as determinants of tumor angiogenesis in squamous cell carcinoma of the esophagus (26). Schoppmann et al (27) indicated that a significant association between HIF-1 $\alpha$ expression and the density of peritumoral lymphatic microvessels provided evidence for a potential role of HIF- $1 \alpha$ as regulator of tumor-associated lymphangiogenesis in breast cancer. Additionally, upregulation of HIF-1 $\alpha$ results in activation of the HIF-1 $\alpha$ /VEGF signaling pathway and promotes hypoxia-induced angiogenesis in lung cancer (28). Under hypoxic conditions, certain cancer cells upregulate VEGF-C protein levels in vitro and in vivo, inducing lymphatic vessel growth in and around the hypoxic tumor environments (29-31). VEGFR-3, which is primarily located in the lymphatic endothelium, is overexpressed under hypoxic conditions in many carcinoma cell lines $(32,33)$. In addition, it serves critical roles during lymphangiogenesis and tumor metastasis in breast cancer (34). HIF-1 $\alpha$ further regulates VEGFR-3 expression in lymphangiogenesis during invasion and metastasis of lung adenocarcinoma and non-small cell lung cancer $(35,36)$. Inspired by this, the current study investigated the role and biological function of HIF-1 $\alpha$ in cLM progression.

To uncover the potential association between HIF- $1 \alpha$ and certain signaling pathways, mRNA expression of HIF-1 $\alpha$, VEGFR-3, VEGF-A, VEGF-C, SHH and TGF- $\beta$ in cLM and adjacent normal tissues was investigated. HIF-1 $\alpha$ and VEGFR-3 expression were significantly elevated at mRNA levels in cLM tissues compared with the normal tissues and higher HIF-1 $\alpha$ and VEGFR-3 protein levels were detected in the cLM tissues. Pearson's correlation analysis revealed a strong positive correlation between HIF-1 $\alpha$ and VEGFR-3 protein expression in cLM tissues. It was hypothesized that a significant upregulation of HIF-1 $\alpha$ may be accompanied by an increase of VEGFR-3 in cLM and that HIF-1 $\alpha$ in conjunction with VEGFR-3 potentially contribute to the progression of cLM.
As previous studies have revealed that HIF-1 $\alpha$ is involved in lymphangiogenesis via regulation of VEGFR-3, the biological role of HIF-1 $\alpha$ in the functional regulation of lymphatic tube formation in HLECs was investigated $(32,35)$. Reports have demonstrated that lymphatic malformations exhibit cobblestone morphology, which is a characteristic of lymphatic endothelial cells $(37,38)$. HIF-1 $\alpha$-overexpressing HLECs were established and co-transfection with si-VEGFR-3 was performed. Transfection efficiency was evaluated by monitoring GFP expression and the success of creating an overexpression or knockdown system was determined by RT-qPCR and western blot. To investigate the role of VEGFR-3 in HIF-1 $\alpha$-overexpressing HLECs, a HIF-1 $\alpha$ overexpression + VEGFR-3 knockdown group and a HIF-1 $\alpha$ group or empty vector control group were compared in colony formation, migration, and lymphangiogenesis assays. The absence of a HIF- $1 \alpha$-overexpression + si-NC control is a limitation of the current study, as effects of siRNA transfection on the HIF-1 $\alpha$-overexpression system were not evaluated. No obvious differences in morphology between the HIF-1 $\alpha$-overexpressing and empty vector HLECs were observed; however, it was determined that HIF-1 $\alpha$ overexpression significantly promoted colony formation and HLEC migration. As cells use glycolysis in the primary mechanism for ATP production under hypoxic conditions, certain HIF-1 $\alpha$ target genes involved in glycolysis may enhance proliferation and migration abilities of cells $(39,40)$. Potentially this mechanism supports how HIF-1 $\alpha$ enhanced HLEC colony formation and migration in the present study. Interestingly, the findings suggested that HIF-1 $\alpha$ overexpression in HLECs accelerated lymphangiogenesis, by reshaping cells into irregular tubes with different dilatations.

HIF-1 $\alpha$-overexpressing HLECs with VEGFR-3 knockdown exhibited decreased levels of colony formation, migration and lymphangiogenesis compared with the HIF-1 $\alpha$-overexpressing cells. It was confirmed that VEGFR-3 protein levels were increased in HIF-1 $\alpha$ overexpression cells during lymphangiogenesis and VEGFR-3 was identified as directly associated with HIF-1 $\alpha$. VEGFR-3 overexpression resulted in similar effects on HLEC colony formation and migration as observed for HIF-1 $\alpha$ overexpression and no significant changes in colony formation and migration were observed for the VEGFR-3 overexpression + HIF-1 $\alpha$ knockdown group compared with the empty vector control.

ATP is an indicator for proliferation $(41,42)$. Results assessing ATP levels during lymphangiogenesis revealed that HIF-1 $\alpha$ overexpression significantly promoted HLEC proliferation. Furthermore, mRNA expression of Prox 1 and LYVE-1, which were previously described to be upregulated in endothelial cells with lymphatic malformations (38), were investigated. It was observed that HIF-1 $\alpha$ overexpression upregulated mRNA expression by targeting VEGFR-3 during the lymphatic tube formation.

As there is no animal model of cLM currently available, in vivo mechanisms were not investigated. Further studies are required to explore whether HIF-1 $\alpha$ contributes to lymphatic tube formations in HLECs via specific signaling pathways and whether HIF-1 $\alpha$ promotes lymphatic malformations in vivo. Further limitations are originating from the missing controls in the co-transfection experiments. To exclude 
potential influences of the secondary transfection step on the system, future research should include all relevant controls (43-47).

In conclusion, the current study demonstrated that HIF-1 $\alpha$ and VEGFR-3 were upregulated in cLM tissues. The role of HIF-1 $\alpha$ was investigated in HLEC colony formation, migration and lymphatic malformations and it was revealed to be associated with VEGFR-3 upregulation in vitro. By understanding the molecular function of HIF-1 $\alpha$ as a promoter of lymphatic malformations, HIF-1 $\alpha$ may become a viable target of future cLM therapeutics.

\section{Acknowledgements}

Not applicable.

\section{Funding}

The current study was supported by the Science and Technique Development Foundation of Nanjing Medical University (grant no. 2015NJMU072).

\section{Availability of data and materials}

All data generated or analyzed during this study are included in this published article.

\section{Authors' contributions}

JZ and WS designed the experiments and conducted the data analyses. TH and YJ performed the clinical sample preparation and validated HIF-1 $\alpha$ and VEGFR-3 expression in cLM specimens. $\mathrm{HC}$ and $\mathrm{YJ}$ performed in vitro assays. JiaC and JieC performed the statistical analyses. TH wrote and edited the manuscript. All authors participated in the discussion and revision of the manuscript. All authors read and approved the final version of the manuscript.

\section{Ethics approval and consent to participate}

The protocols of this study were approved by the Ethics Committee of Children's Hospital of Nanjing Medical University (Nanjing, China). Written informed consent was obtained from all patients or their legal guardians.

\section{Patient consent for publication}

Not applicable.

\section{Competing interests}

The authors declare that they have no competing interests.

\section{References}

1. Wassef M, Blei F, Adams D, Alomari A, Baselga E, Berenstein A, Burrows P, Frieden IJ, Garzon MC, Lopez-Gutierrez JC, et al; ISSVA Board and Scientific Committee: Vascular anomalies classification: Recommendations from the International Society for the study of vascular anomalies. Pediatrics 136: e203-e214 2015 .
2. Florez-Vargas A, Vargas SO, Debelenko LV, Perez-Atayde AR, Archibald T, Kozakewich HP and Zurakowski D: Comparative analysis of D2-40 and LYVE-1 immunostaining in lymphatic malformations. Lymphology 41: 103-110, 2008.

3. Defnet AM, Bagrodia N, Hernandez SL, Gwilliam N and Kandel JJ: Pediatric lymphatic malformations: Evolving understanding and therapeutic options. Pediatr Surg Int 32: 425-433, 2016.

4. Mulliken JB, Burrows PE and Fishman SJ (eds): Mulliken and Young's vascular anomalies: hemangiomas and malformations. 2nd edition. Oxford University Press, Oxford, 2013.

5. Fonkalsrud EW: Lymphatic disorders. In: Pediatric surgery. Grosfeld JL (ed). Mosby/Elsevier, Philadelphia, PA, pp2137-2146, 2006.

6. Sun ZJ, Zhang L, Zhang WF, Liu B, Li ZB and Zhao YF: A possible hypoxia-induced endothelial proliferation in the pathogenesis of epithelioid hemangioma. Med Hypotheses 67: 1133-1135, 2006.

7. North PE, Waner M, Mizeracki A and Mihm MC Jr: GLUT1: A newly discovered immunohistochemical marker for juvenile hemangiomas. Hum Pathol 31: 11-22, 2000.

8. Revencu N, Boon LM, Mendola A, Cordisco MR, Dubois J, Clapuyt P, Hammer F, Amor DJ, Irvine AD, Baselga E, et al: RASA1 mutations and associated phenotypes in 68 families with capillary malformation-arteriovenous malformation. Hum Mutat 34: 1632-1641, 2013

9. Liao D and Johnson RS: Hypoxia: A key regulator of angiogenesis in cancer. Cancer Metastasis Rev 26: 281-290, 2007.

10. Fulda S and Debatin KM: HIF-1-regulated glucose metabolism: A key to apoptosis resistance? Cell Cycle 6: 790-792, 2007.

11. Simon F, Bockhorn M, Praha C, Baba HA, Broelsch CE, Frilling A and Weber F: Deregulation of HIF1-alpha and hypoxia-regulated pathways in hepatocellular carcinoma and corresponding non-malignant liver tissue - influence of a modulated host stroma on the prognosis of HCC. Langenbecks Arch Surg 395: 395-405, 2010.

12. Tao J, Li T, Li K, Xiong J, Yang Z, Wu H and Wang C: Effect of HIF-1alpha on VEGF-C induced lymphangiogenesis and lymph nodes metastases of pancreatic cancer. J Huazhong Univ Sci Technolog Med Sci 26: 562-564, 2006.

13. Katsuta M, Miyashita M, Makino H, Nomura T, Shinji S, Yamashita K, Tajiri T, Kudo M, Ishiwata T and Naito Z: Correlation of hypoxia inducible factor-1alpha with lymphatic metastasis via vascular endothelial growth factor- $\mathrm{C}$ in human esophageal cancer. Exp Mol Pathol 78: 123-130, 2005.

14. Secker GA and Harvey NL: VEGFR signaling during lymphatic vascular development: From progenitor cells to functional vessels. Dev Dyn 244: 323-331, 2015.

15. Tammela T, Saaristo A, Lohela M, Morisada T, Tornberg J, Norrmén C, Oike Y, Pajusola K, Thurston G, Suda T, et al: Angiopoietin-1 promotes lymphatic sprouting and hyperplasia. Blood 105: 4642-4648, 2005.

16. Liang X, Yang D, Hu J,Hao X, Gao J and Mao Z: Hypoxia inducible factor-alpha expression correlates with vascular endothelial growth factor-C expression and lymphangiogenesis/angiogenesis in oral squamous cell carcinoma. Anticancer Res 28 (3A): 1659-1666, 2008.

17. Mizukami Y, Li J, Zhang X, Zimmer MA, Iliopoulos O and Chung DC: Hypoxia-inducible factor-1-independent regulation of vascular endothelial growth factor by hypoxia in colon cancer. Cancer Res 64: 1765-1772, 2004.

18. Boussat S, Eddahibi S, Coste A, Fataccioli V, Gouge M, Housset B, Adnot S and Maitre B: Expression and regulation of vascular endothelial growth factor in human pulmonary epithelial cells. Am J Physiol Lung Cell Mol Physiol 279: L371-L378, 2000.

19. Shen W, Weiping S, Cui J, Chen J and Zou J: Management of cystic lymphangioma in the head and neck region: Endoscopic cautery and postoperative intratumoral negative pressure. J Craniofac Surg 21: 1884-1886, 2010.

20. Livak KJ and Schmittgen TD: Analysis of relative gene expression data using real-time quantitative PCR and the 2(-Delta Delta C(T)) Method. Methods 25: 402-408, 2001.

21. Perkins JA: New frontiers in our understanding of lymphatic malformations of the head and neck: Natural history and basic research. Otolaryngol Clin North Am 51: 147-158, 2018.

22. Ji RC: Hypoxia and lymphangiogenesis in tumor microenvironment and metastasis. Cancer Lett 346: 6-16, 2014.

23. Chen S, Zhang M, Xing L, Wang Y, Xiao Y and Wu Y: HIF-1a contributes to proliferation and invasiveness of neuroblastoma cells via SHH signaling. PLoS One 10: e0121115, 2015. 
24. Stoeltzing O, McCarty MF, Wey JS, Fan F, Liu W, Belcheva A, Bucana CD, Semenza GL and Ellis LM: Role of hypoxia-inducible factor 1alpha in gastric cancer cell growth, angiogenesis, and vessel maturation. J Natl Cancer Inst 96: 946-956, 2004.

25. Nam SY, Ko YS, Jung J, Yoon J, Kim YH, Choi YJ, Park JW, Chang MS, Kim WH and Lee BL: A hypoxia-dependent upregulation of hypoxia-inducible factor- 1 by nuclear factor- $\kappa \mathrm{B}$ promotes gastric tumour growth and angiogenesis. Br J Cancer 104: 166-174, 2011.

26. Kimura S, Kitadai Y, Tanaka S, Kuwai T, Hihara J, Yoshida K, Toge $\mathrm{T}$ and Chayama K: Expression of hypoxia-inducible factor (HIF)-1alpha is associated with vascular endothelial growth factor expression and tumour angiogenesis in human oesophageal squamous cell carcinoma. Eur J Cancer 40: 1904-1912, 2004

27. Schoppmann SF, Fenzl A, Schindl M, Bachleitner-Hofmann T, Nagy K, Gnant M, Horvat R, Jakesz R and Birner P: Hypoxia inducible factor-1alpha correlates with VEGF-C expression and lymphangiogenesis in breast cancer. Breast Cancer Res Treat 99: $135-141,2006$

28. Zhu H and Zhang S: Hypoxia inducible factor-1 $\alpha /$ vascular endothelial grow th factor signaling activation correlates with response to radiotherapy and its inhibition reduces hypoxia-induced angiogenesis in lung cancer. J Cell Biochem 119: 7707-7718, 2018.

29. Morfoisse F, Kuchnio A, Frainay C, Gomez-Brouchet A, Delisle MB, Marzi S, Helfer AC, Hantelys F, Pujol F Guillermet-Guibert J, et al: Hypoxia induces VEGF-C expression in metastatic tumor cells via a HIF-1 $\alpha$-independent translation-mediated mechanism. Cell Reports 6: 155-167, 2014.

30. Kuwai T, Kitadai Y, Tanaka S, Onogawa S, Matsutani N, Kaio E, Ito M and Chayama K: Expression of hypoxia-inducible factor-1alpha is associated with tumor vascularization in human colorectal carcinoma. Int J Cancer 105: 176-181, 2003.

31. Koshikawa N, Iyozumi A, Gassmann M and Takenaga K: Constitutive upregulation of hypoxia-inducible factor-lalpha mRNA occurring in highly metastatic lung carcinoma cells leads to vascular endothelial growth factor overexpression upon hypoxic exposure. Oncogene 22: 6717-6724, 2003.

32. Simiantonaki N, Jayasinghe C, Michel-Schmidt R, Peters K, Hermanns MI and Kirkpatrick CJ: Hypoxia-induced epithelia VEGF-C/VEGFR-3 upregulation in carcinoma cell lines. Int $J$ Oncol 32: 585-592, 2008.

33. Okada K, Osaki M, Araki K, Ishiguro K, Ito $\mathrm{H}$ and Ohgi S: Expression of hypoxia-inducible factor (HIF-1alpha), VEGF-C and VEGF-D in non-invasive and invasive breast ductal carcinomas. Anticancer Res 25: 3003-3009, 2005.

34. Liu ZY, Qiu HO, Yuan XJ, Ni YY, Sun JJ, Jing W and Fan YZ: Suppression of lymphangiogenesis in human lymphatic endothelial cells by simultaneously blocking VEGF-C and VEGF-D/VEGFR-3 with norcantharidin. Int J Oncol 41: $1762-1772,2012$
35. Su JL, Yen CJ, Chen PS, Chuang SE, Hong CC, Kuo IH, Chen HY, Hung MC and Kuo ML: The role of the VEGF-C/VEGFR-3 axis in cancer progression. Br J Cancer 96: 541-545, 2007.

36. Teng X, Li D and Johns RA: Hypoxia up-regulates mouse vascular endothelial growth factor D promoter activity in rat pulmonary microvascular smooth-muscle cells. Chest 121 (Suppl): 82S-83S, 2002.

37. O TM, Lou MS and Ma Y; O TM: Zinc effect on human lymphatic malformation cells in vitro. Int J Pediatr Otorhinolaryngol 80: 33-38, 2016.

38. Boscolo E, Coma S, Luks VL, Greene AK, Klagsbrun M, Warman ML and Bischoff J: AKT hyper-phosphorylation associated with PI3K mutations in lymphatic endothelial cells from a patient with lymphatic malformation. Angiogenesis 18: 151-162, 2015.

39. Semenza GL: HIF-1 mediates metabolic responses to intratumoral hypoxia and oncogenic mutations. J Clin Invest 123: 3664-3671, 2013

40. Hong SS, Lee H and Kim KW: HIF-1alpha: A valid therapeutic target for tumor therapy. Cancer Res Treat 36: 343-353, 2004.

41. Oliveira SL, Trujillo CA, Negraes PD and Ulrich H: Effects of ATP and NGF on Proliferation and Migration of Neural Precursor Cells. Neurochem Res 40: 1849-1857, 2015.

42. Chen JB, Liu WJ, Che H, Liu J, Sun HY and Li GR Adenosine-5'-triphosphate up-regulates proliferation of human cardiac fibroblasts. Br J Pharmacol 166: 1140-1150, 2012

43. Song X, Rui C, Meng L, Zhang R, Shen R, Ding H, Li J, Li J and Long W: Long non-coding RNA RPAIN regulates the invasion and apoptosis of trophoblast cell lines via complement protein C1q. Oncotarget 8: 7637-7646, 2017.

44. Xia H, Li Y and Lv X: MicroRNA-107 inhibits tumor growth and metastasis by targeting the BDNF-mediated PI3K/AKT pathway in human non-small lung cancer. Int J Oncol 49: $1325-1333,2016$

45. Xie F, Huang Q, Liu CH, Lin XS, Liu Z, Liu LL, Huang DW and Zhou HC: MiR-1271 negatively regulates AKT/MTOR signaling and promotes apoptosis via targeting PDK1 in pancreatic cancer. Eur Rev Med Pharmacol Sci 22: 678-686, 2018.

46. Wang J, Yang S, Ge W, Wang Y, Han C and Li M: MiR-613 suppressed the laryngeal squamous cell carcinoma progression through regulating PDK1. J Cell Biochem 119: 5118-5125, 2018.

47. Dai J, Wang J, Yang L, Xiao Y and Ruan Q: miR-125a regulates angiogenesis of gastric cancer by targeting vascular endothelial growth factor A. Int J Oncol 47: 1801-1810, 2015

This work is licensed under a Creative Commons Attribution-NonCommercial-NoDerivatives 4.0 International (CC BY-NC-ND 4.0) License. 